Інноватика у вихованні. Випуск 14. 2021.

УДК: 378

DOI: $\underline{10.35619 / \text { iiu.v1i14.346 }}$

Потапчук Тетяна

доктор педагогічних наук, професор, професор кафедри теорії та методики дошкільної і спеціальної освіти ДВНЗ «Прикарпатський національний університет імені Василя Стефаника», м. Івано-Франківськ, Україна ORCID: 0000-0003-1680-6976 e-mail:tatvolod@ukr.net

Клепар Марія доктор педагогічних наук, професор кафедри педагогіки початкової освіти ДВНЗ «Прикарпатський Національний університет імені Василя Стефаника», м. Івано-Франківськ, Україна ORCID: 0000-0003-4923-8696 e-mail: mklepar10@gmail.com Фабрика-Процька Ольга доктор мистецтвознавства, професор кафедри музичної україністики та народно-інструментального мистецтва Навчально-наукового Інституту мистецтв ДВНЗ «Прикарпатський університет імені Василя Стефаника»,

м. Івано-Франківськ, Україна ORCID: 0000-0001-5188-1491 e-mail:olgafp4@ukr.net

\title{
МУЗИЧНЕ МИСТЕЦТВО ЯК ЗАСІБ ФОРМУВАННЯ МОРАЛЬНО-ДУХОВНИХ ЦІННОСТЕЙ МОЛОДШИХ ШКОЛЯРІВ
}

Анотація. Визначення статусу мистецтва, зокрема, музичного, та розуміння діяльнісної перспективи впливу музики на моральність та духовність учня, допоможе розв'язати основне питання музичнопедагогічної освіти, постулатом якої стає становлення особистості (інтелектуальне та художнє) як результат іiі саморозвитку і розвитку іiі творчих потенцій, що забезпечить всебічну підготовку молодшого школяра.

Відомо, що музичне мистецтво має властивість не лише формувати емоційний досвід, але й просвітлювати, очищати людські переживання. Цей очищувальний вплив - катарсис $\epsilon$ доказом зв'язку музичної творчості 3 вищими людськими цінностями. Музичне мистецтво перш за все мистецтво емоцій, проте це мистецтво здатне впливати на інтелектуальну

(C) Потапчук Т., Клепар М., Фабрика-Процька О., 2021 


\section{Інноватика у вихованні. Випуск 14. 2021.}

сферу особистості, збагачуючи ії знання про морально-духовні цінності. У цьому випадку музичний твір $є$ джерелом інформації про художній світогляд певного періоду, напряму, національної школи митця.

Впливаючи на людину насамперед через переживання, музичне мистецтво володіє унікальною здатністю активізувати емоційну сприйнятливість, збагачувати досвід почувань, а, отже, всебічно розвивати особистість, ії ціннісні установки, загальну культуру. Завдяки моральнодуховним цінностям, музичне мистецтво, особливо духовна музика, дає людині можливість пережити чуже життя як своє, збагатитися досвідом багатьох поколінь, зробити його фактом свого буття. Мистецтво спонукає до співпереживання (емпатіi), співчуття, здатності зрозуміти емоційний стан іншої людини (синтонії), сприяє формуванню людських відносин, зокрема й морально-духовних цінностей.

Ключові слова: музичне мистецтво, духовна музика, емоції, морально-духовні цінності, молодші школярі.

Постановка проблеми. Музика у формі «мистецтва», вважалась вираженням «розумних почуттів», і як високоморальне явище святковою, що потребує для свого сприйняття естетично i етично освічену особистість.

Музика у формі «не мистецтва», як правило, не потребує спеціальної «теоретичної» підготовки, позаяк вона орієнтована на збудження «нерозумних» емоцій. Така музика також виконує багато функцій: звільняє людину від тиску, формує особливе розуміння свободи, підтримує в душах людей агресивний руйнівний пафос, що має своєрідний терапевтичний ефект. Зростання ролі і значущості музики - «не мистецтва», сприяє розвитку аудіо і відеотехніки, комп’ютерних технологій.

До кінця XX ст. через відсутність ідеологічного, естетичного, етичного «нагляду» роль подібної музики у визволенні людських афектів підвищується, що відтісняє музику - «мистецтво» 3 iї високим терапевтичним і виховним потенціалом на культурну периферію.

Слід також відмітити обов'язковий зв'язок музично-теоретичних знань 3 морально-духовними. Значення моральних понять і категорій етики в їх позитивному впливі на музично-теоретичні знання надзвичайно важливе. Розуміння специфіки образної системи музики, умовності іiі форм, допомагає емоційно й глибинно сприймати твір та інтерпретувати його.

На думку О. Лосєва, «Музика приводить у вібрацію саму душу людини: вона діє безпосередньо на організм душі, викликаючи в ній глибокі і найпотаємніші хвилювання. Образне ж мистецтво ставить між душею людини і предметом пізнання образ, тобто відому структуру свідомості, і через цю структуру душа і відчуває буття» (Лосев, 1995, с. 305).

Зокрема, В. Толстих (1973) підкреслює, що співпереживання як людське почуття, пронизує усі види людської діяльності, серед них i 


\section{Інноватика у вихованні. Випуск 14. 2021.}

контакт 3 мистецтвом: досвід почуттів суспільної людини включає в себе не лише їі індивідуальні переживання, але й увесь досвід емоційних співпереживань, отриманих в процесі спілкування з іншими людьми у всіх сферах людської життєдіяльності, включаючи і досвід контактування зі світом мистецтва (Толстых, 1973, с. 323).

Аналіз останніх досліджень 3 проблеми. Проблема формування морально-духовних цінностей нерозривно пов'язана 3 аналізом музичних творів і загально-моральною підготовкою учнів. На необхідність поєднання музикознавчого та морально-духовного підходу в аналізі музичного мистецтва вказують Л. А. Мазель, Ю. Холопов, С. Х. Раппопорт.

У наукових працях останніх років досить часто розглядаються різні аспекти формування морально-духовних цінностей особистості засобами духовної музики. Зокрема, узагальнення досвіду вивчення творів духовної музики вітчизняних композиторів та аналіз місця музичного мистецтва у моральному вихованні особистості аналізується у працях Н. А. Герасимової-Персидської, В. В. Медушевського, О. П. Рудницької та iH.

Мета статті - провести теоретичне дослідження проблеми моральнодуховних цінностей молодших школярів засобами музичного мистецтва, визначити виховний вплив духовної музики на особистість молодшого школяра.

Виклад основного матеріалу дослідження. Завдяки музиці ми пізнаємо всі відтінки радості, горя, страждань і щастя, які ми, можливо, i не переживали у житті, але які відчуваємо, дякуючи музиці.

Зокрема, Б. М. Теплов (1947), слушно наголошує на внутрішній емоційності музичного пізнання дійсності, «Переживання музики має бути емоційним. Сприймання музики відбувається через емоцію, але емоцією воно не закінчується. В музиці ми пізнаємо світ. Музика є емоційне пізнання» (Теплов, 1947, с.22). «Почуття незрівнянно повніше, глибше, точніше можуть бути виражені засобами музики, ніж словами. Тому неможливо адекватно і до кінця перевести у слова зміст музики. Цей переклад обов'язково буде неповним, грубим і приблизним... Але 3 неможливості переведення у слова змісту музики зовсім не слідує, що сам цей зміст $є$ невизначеним і розпливчатим. Емоційний зміст дійсно значного твору музики досконально визначеної» (Теплов, 1947, с.12).

На думку Л. Виготського (1991), складний світ переживань і почуттів, який розширюється і поглиблюється у процесі контактування з музикою, складає психологічну основу мистецтва музики (Выготский, 1991, с.15). Він назвав мистецтво «суспільною технікою почуттів» і стверджував, що все прикладне значення мистецтва зводиться до його виховної дії (Выготский, 1991, с.322).

С. Л. Рубінштейн (1959) стверджував, що сам перехід життєвих ставлень в систему вироблених музикою засобів виразності вже забезпечує ефект «універсальності», «суспільної величності» музичного мистецтва. 


\section{Інноватика у вихованні. Випуск 14. 2021.}

Отже, музика має широкі можливості у пізнанні світу, бо вона у концентрованому вигляді втілює в собі багатство і різнобічність його сутності, духовного життя і особистісного «Я».

Вплив музичного мистецтва на формування морально-духовних цінностей молодших школярів починається у дитинстві. Змалку дитина відчуває усяке моральне занедбання, відразу до поганого, те, що недобре 3 самої природи. Вона захоплюється красою, що властива моральному добру, живить нею свої розум і почуття ще до того, як зможе іії усвідомити. Коли настає пора усвідомлення істин християнського бутя, сприймає їх як дуже близькі.

Вагомим є переконання, що виховання засобами музичного мистецтва допомагає подолати суперечності між суспільними та індивідуальними інтересами задля вивільнення етичного початку з-під влади практичного інтересу - особистого благополуччя.

У нашому дослідженні музичне мистецтво буде визначатися як духовні музичні твори композиторів різних епох, за допомогою яких виховуються естетичні, моральні якості, духовні цінності особистості.

Духовна музика - це, передусім релігійні піснеспіви, які виражають душевний стан людини, уможливлюють певне моральне відчуття. Тому спосіб існування духовної музики має відповідати ії духовному змістові.

Духовна музика надзвичайно важлива й з огляду на те, що менталітету українців властиві чуттєвість, внутрішня потреба творити прекрасне. «Наше єство, - стверджував I. Вознесенський, - так насолоджується піснеспівом, що невгамовані немовлята засинають під спів. Співають всі і всюди: у церкві, вдома, а в церкві - псалми як джерело освячення дають ще більшу користь і задоволення» (Вознесенский, 1905).

Великий вплив духовної музики на суб'єктивний світ особистості та колективну свідомість особистості. Вона є естетичним засобом пізнання життя людини, етноспільноти, народу.

Свого часу М. Рубінштейн $(1917$, с.56) писав, що молитва виливається у форму співу та музики, і зазвичай лише так релігійне почуття пробуджується до нового життя. Спів - це осердя православного богослужіння. Коли наші предки казали, що «Церква Божа без співу стоїть», то це означало, що вона порожня і не діє. Розспіви у Православній церкві в періоди ії розквіту, як і богослужбові тексти, називалися святими. I якщо проповідування Божого Слова завжди було повчальним, то церковний піснеспів давав змогу заглибитися розумом і серцем у зміст виконуваного i мимоволі пробуджував комплекс релігійних почуттів (Кураев, 1997, с.20).

На думку П. Щуровського, «Церковна музика здатна викликати у прихожан урочистий настрій, примушувати їх відмовлятися від усього земного, навертати душі до Божественного» (Щуровский, 1898, с.12 - 13). Спів, зазначає В. Лебедєв, сповнює людей високими небесними відчуттями (Лебедев, 1907, с.3). У церковному співі на текст Святого Письма складається мелодія. Адже в Православній Церкві інструментальної 


\section{Інноватика у вихованні. Випуск 14. 2021.}

музики немає, наразі голос вважається природним i найкращим інструментом. Цей піснеспів називається богослужбовим, церковним. «Духовна музика, покликана до піднесеного життя. Вона не допускає нечистого, неспівзвучного, не дає душі стати глухою» (Лебедев, 1907).

Духовні піснеспіви $є$ наслідком індивідуальних вражень, афектів окремо взятої особистості через сприйняття нею релігійних істин. Вони не здатні породжувати стійке моральне почуття через відсутність зв'язку 3 духовною традицією. Проте збуджують емоційність, доводять до стану душевної неврівноваженості. Наявність під час сприйняття духовних піснеспівів, виражених настановлень на художність, відчуттєву впливовість порівняно 3 явищем духовної музики спричинюють суперечності між художніми та морально-творчими аспектами музичнодуховної діяльності.

Тому церковний спів гармонізує душу i розум людини, сприяє усвідомленню змісту моральних уроків Закону Божого. Завдання сьогодні, полягає в тому, аби мистецтво, до якого долучаються прихожани у церкві, піднести на вищий рівень. I тоді парафіяни виховуватимуться на справжніх художніх творах, а в майбутньому прагнутимуть розширити свій художній світогляд.

У багатьох дослідженнях духовна музика розглядається 3 позицій історичної ретроспективи змісту та основних форм роботи на уроці. Зокрема, вчені розглядають духовну музику в загальному аспекті як обов'язкову складову музичної освіти (поряд із народною та музикою зарубіжних композиторів). На уроці, на переконання дослідника, вона має бути суто у хоровому виконанні, а в роботі здебільшого використовувати метод емпіричного сприйняття. Вчені зауважують, що освітня та виховна функція церковного співу не підлягає сумніву, адже, крім музичних знань, вона дає значну кількість літургічних, історичних та літературних повідомлень.

Під час прослуховування улюблених творів школярі концентрують увагу на власних думках і почуттях; керуючись голосом совісті, виділяють позитивні і негативні якості.

На уроці під час вивчення твору М. В. Лисенка «Боже Великий, Сдиний» ми розповідали про виховний потенціал творів українського хорового мистецтва. При цьому підкреслювалося, що діяльність композитора визначалася не тільки написанням музичних творів, що відрізнялися гармонійною красою і виразністю, але й їх використанням у моральному вихованні тогочасної молоді.

У процесі розучування творів звертали увагу молодших школярів на основні засоби музичної виразності (темп, динаміку, лад, мелодію), які використовує композитор, зосередивши увагу на тому, що церковну молитву автор наближає до художньо-емоційного еталону класичного музичного мистецтва. Пісенний характер творів М. В. Лисенка слугував одним із відправних моментів у створенні художньо-повноцінних моральних образів у моральній свідомості молодших школярів. 


\section{Інноватика у вихованні. Випуск 14. 2021.}

При вивченні духовної музики на заняттях музичного мистецтва в учнів формуються такі морально-духовні цінності, як шляхетність, старанність, смирення, делікатність, шанобливість, скромність, лагідність, урівноваженість тощо.

Висновки і перспективи подальших розвідок. Тож, духовна музика як цілісна структура - це не лише особливий світ образів, думок, почуттів, а й відмінна від решти мистецтв інтонаційна сфера, з притаманним лише ій тематикою та законами його розвитку. Виконане дослідження не вичерпує всіх аспектів зазначеної проблеми. Подальшої розробки потребують питання інтерпретації творів духовної музики зі старшими школярами.

\section{СПИСОК ВИКОРИСТАНИХ ДЖЕРЕЛ}

Лосев, А. (1995). Строение музыкального мироощущения. Форма-СтильВыражение. Сост. А. А. Тахо-Годи. Москва: Мысль. 944 с.

Толстых, В. (1973). Искусство и мораль: О социальной сущности и функциях искусства. Москва : Политиздат, 440 с.

Теплов, Б. (1947). Психология музыкальных способностей. Изд. АПН СССР. Москва, 335 с.

Выготский, Л. (1991). Воображение и творчество в детском возрасте. Психологический очерк. Кн. для учителя. 3-е изд. Москва: Просвещение, 90 с.

Рубинштейн, С. (1959). Проблема способностей и вопросы психологической теории: тезисы докладов на I съезде общества психологов. Москва, Вып. 3. С. 138.

Вознесенский, И. (1905). Общее церковное пене. Народно-певческие хоры. M., $66 \mathrm{c}$.

Кураев, А. (1997). Школьное Богословие. Москва: Фонд «Благовест», 96 с.

Щуровский, П. (1898). Как нужно обучать наших детей музыке. Москва, 40 с.

Лебедев, В. (1907). Общее церковное пение; народно-певческие хоры. Тамбов, $66 \mathrm{c}$.

Рубинштейн, М. (1917). Эстетическое воспитание детей. 3-е изд. Москва, $153 \mathrm{c}$.

\section{REFERENCES}

Losev, A. (1995). Stroenie muzyikalnogo mirooschuscheniya. [The structure of the musical worldview]. Forma-Stil-Vyirazhenie. Sost. A. A. Taho-Godi. Moskva.: Mysl. 944 s. [in Russian].

Tolstykh, V. (1973). Iskusstvo i moral: O sotsialnoy suschnosti $i$ funktsiyakh iskusstva [Art and morality: On the social essence and functions of art]. Moskva: Politizdat, 440 s. [in Russian].

Teplov, B. (1947). Psihologiya muzyikalnykh sposobnostey [Psychology of musical abilities]. Izd. APN SSSR. Moskva, 335 s. [in Russian].

Vygotskiy, L. (1991). Voobrazhenie i tvorchestvo v detskom vozraste. [Imagination and creativity in childhood]. Psihologicheskiy ocherk. Kn. dlya uchitelya. 3-e izd. Moskva: Prosveschenie, 90 s. [in Russian].

Rubinshtein, S. (1959). Problema sposobnostey i voprosy psihologicheskoy teorii: tezisy dokladov na I sezde obschestva psihologov [The problem of abilities and questions of psychological theory: abstracts of reports at the First Congress of the Society of Psychologists]. Moskva, Vyp. 3. S. 138. [in Russian]. 


\title{
Інноватика у вихованні. Випуск 14. 2021.
}

Voznesenskiy, I. (1905). Obschee tserkovnoe penie [General church foam. Folk singing choirs]. Narodno-pevcheskie hory. Moskva, 66 s. [in Russian].

Kuraev, A. (1997). Shkolnoe Bogoslovie [School Theology]. Moskva: Fond „Blagovest”, 96 s. [in Russian].

Schurovskiy, P. (1898). Kak nuzhno obuchat nashih detey muzyke [How to teach our children music]. Moskva., 40 s. [in Russian].

Lebedev, V. (1907). Obschee tserkovnoe penie; narodno-pevcheskie hory [General church singing; folk singing choirs]. Tambov, $66 \mathrm{~s}$. [in Russian].

Rubinshteyn, M. (1917). Esteticheskoye vospitaniye detey [Aesthetic education of children]. 3-e izd. Moskva, 153 s. [in Russian].

\section{MUSICAL ART AS A MEANS OF FORMATION OF MORAL AND SPIRITUAL VALUES OF JUNIOR SCHOOLCHILDREN}

\author{
Tetiana Potapchuk \\ Doctor of Sciences (in Pedagogy), Professor, \\ Professor at the Department of Theory \\ and Methods of Preschool and Special Education \\ of Vasyl Stefanyk Precarpathian National University, \\ Ivano-Frankivsk, Ukraine \\ ORCID 0000-0003-1680-6976 \\ e-mail:tatvolod@ukr.net \\ Maria Klepar \\ Doctor of Sciences (in Prdagogy), \\ Professor at the Department of Pedagogy of Primary Education \\ of Vasyl Stefanyk Precarpathian National University, \\ Ivano-Frankivsk, Ukraine \\ ORCID: 0000-0003-4923-8696 \\ e-mail: mklepar10@gmail.com \\ Olha Fabryka-Protska \\ Doctor of Study of Art, Professor at the Department of \\ Musical Ukrainian Studies and Folk Instrumental Music, \\ Art Institute of Art of Vasyl Stefanyk Precarpathian National University, \\ Ivano-Frankivsk, Ukraine \\ ORCID: 0000-0001-5188-1491 \\ e-mail:olgafp4@ukr.net
}

\begin{abstract}
Determining the status of art, in particular, music, and understanding the perspective of music on the morality and spirituality of the student, will help solve the main issue of music education, the postulate of which is the formation of personality (intellectual and artistic) as a result of its selfdevelopment and development of its creative, which will provide a comprehensive preparation of primary school. It is known that the art of music has the ability not only to form an emotional experience, but also to enlighten, purify human experiences. This cleansing effect - catharsis - is proof of the connection between musical creativity and higher human values.
\end{abstract}




\section{Інноватика у вихованні. Випуск 14. 2021.}

Musical art is primarily the art of emotions, but this art is able to influence the intellectual sphere of the individual, enriching his knowledge of moral and spiritual values. In this case, the musical work is a source of information about the artistic worldview of a certain period, direction, national school of the artist. Influencing a person primarily through experience, the art of music has a unique ability to activate emotional receptivity, enrich the experience of feelings, and, consequently, comprehensively develop the personality, its values, generic culture.

Due to moral and spiritual values, musical art, especially spiritual music, gives a person the opportunity to live another's life as his own, to enrich the experience of many generations, to make it a fact of his existence. Art encourages empathy, compassion, the ability to understand the emotional state of another person (syntony), promotes the formation of human relationships, including moral and spiritual values.

Of all the arts, music most vividly expresses the essence of the inner, personal life of man, and hence life in general, because self-observation is generally the only source of knowledge of the depths of existence.

Keywords: music art, spiritual music, emotions, moral and spiritual values, junior schoolchildren.

Стаття надійшла до редакиії 08.09.2021p. 